удк 332.132

\title{
ПРІОРИТЕТНІ НАПРЯМИ МОДЕРНІЗАЦІЇ ЕКОНОМІКИ ЗАХІДНОГО РЕГІОНУ УКРАЇНИ: БІОЕКОНОМІЧНИЙ АСПЕКТ
}

\section{PRIORITY DIRECTIONS OF MODERNIZATION OF THE ECONOMY OF THE WESTERN REGION OF UKRAINE: BIOECONOMIC ASPECT}

\author{
Проскура Володимир Федорович \\ доктор економічних наук, профресор, \\ Мукачівський державний університет \\ ORCID: https://orcid.org/0000-0001-5494-0039 \\ Білоус Світлана Петрівна \\ кандидат економічних наук, доцент, \\ Черкаський національний університет імені Богдана Хмельницького \\ ORCID: https://orcid.org/0000-0002-0303-7453 \\ Proskura Volodymyr \\ Mukachevo State University \\ Belous Svitlana \\ Cherkasy National University named after Bohdan Khmelnytsky
}

\begin{abstract}
Досліджено стратегії розвитку регіонів. Обґрунтовано, що пріоритетний напрям економічного розвитку західного регіону України сьогодні це модернізація його економіки шляхом децентралізації та запровадження широкої різноманітності у технологіях виробництва. Визначено пріоритетні напрямки розвитку господарств в домінуючих економічних комплексах західного регіону України. Сфрормовано шляхи державної підтримки економічного розвитку західного регіону України. Виокремлено ключові інструменти державної підтримки для реалізації цих шляхів. Виокремлено основні галузі біоекономіки західного регіону України і обґрунтовано доцільність залучення інвестицій в них. Доведено, що реструктуризацію економічного потенціалу західного регіону України слід проводити у таких напрямках: посилення збалансованості соціально-економічного і екологічного розвитку; розвиток біоекономіки; впровадження інновацій в усіх галузях господарства західного регіону України, особливо інноваційний розвиток виробничої, комунікаційно-інфрормаційної, соціальної інфрраструктури; інтенсивний розвиток рекреаційного комплексу.
\end{abstract}

Ключові слова: біоекономіка, стратегічний розвиток, стратегія регіону, державна підтримка, регіональна економіка, модернізація.

Исследованы стратегии развития регионов. Обосновано, что приоритетное направление экономического развития западного региона Украины сегодня это реструктуризация его экономики путем децентрализации и внедрение широкого разнообразия в технологиях производства. Определены приоритетные направления развития хозяйств в доминирующих экономических комплексах западного региона Украины. Сформированы пути государственной поддержки экономического развития западного региона Украины. Выделены ключевые инструменты государственной поддержки для реализации этих путей Выделены основные отрасли биоэкономики западного региона Украины и обоснована целесообразность привлечения инвестиций в них. Доказано, что реструктуризацию экономического потенциала западного региона Украины следует проводить в следующих направлениях: усиление сбалансированности социально-экономического и экологического развития; развитие биоэкономики; внедрение инноваций во всех отраслях хозяйства западного региона Украины, особенно инновационное развитие производственной, коммуникационно-информационной, социальной инфраструктуры; интенсивное развитие рекреационного комплекса.

Ключевые слова: биоэкономика, стратегическое развитие, стратегия региона, государственная поддержка, региональная экономика, модернизация. 
Regional development strategies are studied. It is substantiated that the priority direction of economic development of the western region of Ukraine today is the restructuring of its economy through decentralization and the introduction of a wide variety of production technologies. The priority directions of economic development in the dominant economic complexes of the western region of Ukraine are determined. Ways of state support of economic development of the western region of Ukraine are formed. The key instruments of state support for the implementation of these ways are identified, namely: support for the development of regional infrastructure through subventions; construction of new enterprises on the basis of providing favorable conditions; creation of professional state structures (departments) for attracting investments, professional support of investors; infrastructural support of business activity - exhibition areas, industrial parks, business centers, etc.; creation of infrastructure in a certain territory for the location of new enterprises and comprehensive assistance from the state; providing investment support for the implementation of energy-saving technologies; comprehensive support. Priority areas for supporting small and medium-sized businesses have been identified. This comprehensive support should be implemented in the following areas: creation of regional business support centers; introduction of an effective credit-guarantee mechanism for microcredit of business; financing of small business with the help of international credit programs specially developed for small business and "startup" projects; increasing the motivation of regional state authorities and regional self-government in the direction of creating favorable starting conditions for the placement of small and medium-sized businesses by reducing the share of tax revenues that go to the central state budget; encouraging the introduction of innovations in production and economic activities. The main branches of bioeconomy of the western region of Ukraine are singled out and the expediency of attracting investments in them in the first place is substantiated. It is proved that the restructuring of the economic potential of the western region of Ukraine should be carried out in the following areas: strengthening the balance of socio-economic and environmental development; bioeconomy development; introduction of innovations in all sectors of the economy of the western region of Ukraine, especially innovative development of production, communication and information, social infrastructure; intensive development of the recreational complex.

Keywords: bioeconomy, strategic development, strategy of the region, state support, regional economy, modernization.

Постановка проблеми. Основним вектором в управлінні економікою регіону є стратегія його розвитку. Стратегії розвитку регіону присвячено багато наукових досліджень, проте все одно залишаються питання, які потребують наукового обґрунтування. При розробці стратегії регіону її можна представити, як комплексний процес змін регіональної економічної, соціальної, екологічної, просторової, політичної і духовної сфрер, що приводить до їх якісних перетворень i, в кінцевому підсумку, - до змін умов життя людини. Тому, стратегія регіону має бути націлена в напрямку суспільного прогресу, що виявляється в збільшенні суспільного багатства, тобто всієї сукупності об'єктивних і суб'єктивних умов життєзабезпечення і життєдіяльності людини, і гармонічному розвитку на цій основі самої людини, природи, виробництва, суспільства і держави.

Аналіз останніх досліджень і публікацій. Сьогодні науковцями обґрунтовано досить багато стратегій розвитку регіону. Так, в [1, с. 7-9] пропонуються такі складові з управління розвитком регіону: в умовах потреби інституціональної та структурної перебудови суспільства продукування політико-економічних та культурних умов для задоволення цієї потреби; заходи для поширення наслідків прогресу щодо максимально широкого кола населення; розподіл процесів прийняття рішень щодо реструктуризації регіональних економік.
Хоча, стратегічне планування комерційних організацій і його традиційні технології - бізнес-плани і комерційні проекти - не отримали широкого застосування в регіональному плануванні. Однак, сьогодні до стратегічного планування звертаються все більше суб'єктів господарської діяльності та органи державного управління в тому числі - регіональні.

У доресормений період стратегія розглядалася тільки як результат довгострокового планування, як дещо засріксоване й усталене. Останнім часом серед фрахівців зі стратегічного планування стало переважати нове розуміння стратегії як поєднання раціонально виробленої стратегії і надзвичайної стратегії, обумовленої, в першу чергу, шаблонами, моделями в потоці рішень і дій [2-9]. Тобто, така стратегія $є$ результатом взаємодії планових і незапланованих дій. Такий підхід до визначення стратегії обумовлений високим ступенем мінливості сучасного світу - майбутнє непередбачуване; визначеності немає ні в чому; немає достовірних прогнозів; цілі постійно змінюються, так само як і зовнішні умови.

Таким чином можна відзначити, що вивченням напрямів розвитку економіки регіону 3 позиції біоекономіки займалися провідні українські та зарубіжні автори, а саме: Адамов Б.І., Алексеев О.Б., Алексеева М.М., Анисимов О.С., Балян А.В., Без'язичний В., Бланк И.А., Бойко 3.М., Загородній А.Г., Мамонова В., Мошенець О.С., Софріщенко І., Стадницький Ю.І., Черевко О.В. та ін. 
Формулювання цілей статті. Дослідити, проаналізувати та визначити пріоритетні напрями розвитку економіки західного регіону України з позиції біоекономіки.

Виклад основного матеріалу дослідження. Пріоритетний напрям економічного розвитку західного регіону України сьогодні це реструктуризація його економіки шляхом децентралізації та запровадження широкої різноманітності у технологіях виробництва.

При запровадженні таких напрямів розвитку 3'явиться можливість значно покращити ефективність використання ресурсів у виробництві та запровадити нові виробничі потужності, а це в свою чергу покращить рівень зайнятості регіону. В тому числі не обійдеться і без реструктуризації традиційних галузей регіону з існуючим максимальним зношенням основного капіталу (рис. 1).

Шляхи державної підтримки при цьому повинні спиратися на визначення стратегічних цілей розвитку регіону та максимізацію залучення в ці напрямки інвестицій.

Розвиток людських ресурсів та інсрраструктури регіону $€$ передумовою зосередження інвестицій в регіоні. Саме вчасне інформування інвесторів та рекламація інвестиційних можливостей регіону є запорукою залучення великої кількості інвестицій [10].

Спрямованість регіональної політики повинна проявлятися в державній підтримці регіонів завдяки чому регіони зможуть підвищити свою конкурентоспроможність на ринку інвестицій в середовищі існування жорсткої конкуренції між ними. Така система може бути створена виключно за прямої підтримки фрункціонування з державного бюджету та запровадження широкого інвестиційного клімату [11].

Головні інструменти, з позиції держави для реалізації цих шляхів повинні включати: підтримку розвитку регіональної інфрраструктури за допомогою субвенцій; спорудження нових підприємств на основі забезпечення цьому сприятливих умов; створення професійних державних структур (відділів) 3 залучення інвестицій, профресійного супроводу інвесторів; інсрраструктурна підтримка підприємницької діяльності - виставкових площ, промислових парків, бізнес-центрів, інше; створення інфрра-

\begin{tabular}{|c|c|c|}
\hline \begin{tabular}{ll} 
& \multicolumn{1}{c}{ Агропромисловий } \\
комплекс & молочна галузь \\
- & фруктозаготівель \\
& на галузь \\
- & жиропереробна \\
& галузь \\
- & вовняна галузь
\end{tabular} & 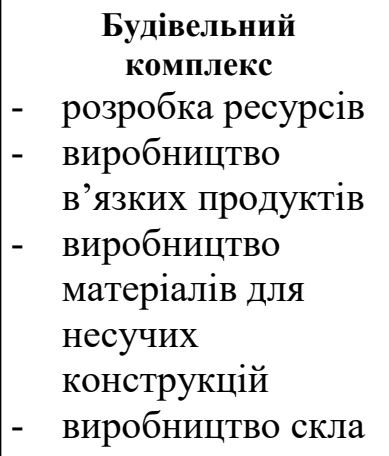 & \begin{tabular}{|l} 
Лісовиробничий \\
комплекс
\end{tabular} \\
\hline \begin{tabular}{ll}
\multicolumn{1}{c}{ Комплекс } \\
виробництва товарів \\
\multicolumn{1}{c}{ народного } \\
споживання \\
- \\
- & текстильна галузь \\
- & трикотожажне \\
виробництво \\
- & лляна \\
- & промисловість \\
& шкіряно-взуттєва \\
галузь & швейна \\
промисловість
\end{tabular} & 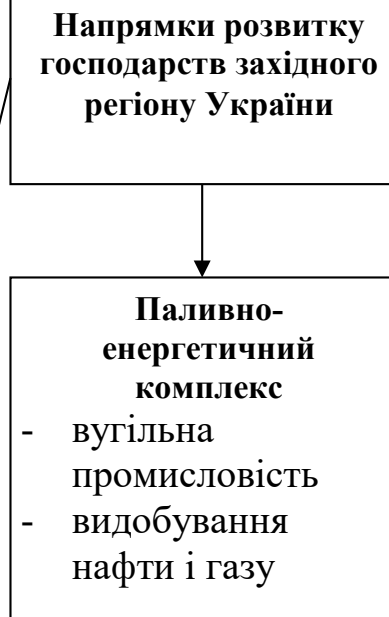 & \begin{tabular}{|l} 
Хімічний комплекс \\
- поглиблення в \\
комплексній \\
хімічній \\
переробці \\
органічного \\
палива \\
- \\
більш повне \\
використання \\
місцевих \\
сировинних \\
ресурсів
\end{tabular} \\
\hline
\end{tabular}

Рис. 1. Пріоритетні напрямки розвитку господарств в домінуючих економічних комплексах західного регіону України 
структури на певній території для розміщення нових підприємств та всебічне сприяння 3 боку держави; забезпечення інвестиційної підтримки для реалізації енергозберігаючих технологій; всебічна підтримка малого і середнього бізнесу. Ця всебічна підтримка повинна бути реалізована у таких напрямах: створення регіональних центрів підтримки бізнесу; введення дійового кредитно-гарантійного механізму мікрокредитування бізнесу; фрінансування малого бізнесу за допомогою міжнародних кредитних програм спеціально розроблених саме для малого бізнесу та проектів «стартапів»; підвищення мотивування регіональної державної влади та регіонального самоврядування в напрямку створення вигідних вихідних умов для розміщення дрібного і середнього бізнесу через зменшення частини податкових надходжень, які спрямовуються в центральний державний бюджет; заохочення до впровадження інновацій в виробничо-господарській діяльності. Саме науково-технічні розробки та запровадження у виробничому процесі інновацій є рушієм його економічного розвитку (рис. 2).
Унаслідок існування багатьох науководослідних інститутів та нахилу до здійснення високотехнологічної та наукоємної продукції саме західний регіон України і повинен в першу чергу розвиватися в даному напрямку.

Держава в свою чергу мусить надавати підтримку в напрямах: взаємодії суб'єктів господарської діяльності всіх напрямів (бізнес, освіта, фрінансова, інвестиційні фронди, інше). Також повинні працювати системи регулювання при розподілі інноваційних проектів в умовах пріоритетності регіонального розвитку. При визначенні пріоритетів регіональних напрямів інноваційного розвитку держава повинна сприяти скупченню відповідних інтелектуальних, а також фрінансових ресурсів для реалізації виробничо-господарської діяльності у цих напрямах.

Тут же важливим є впровадження інвестицій у розвиток висококваліфікованих спеціалістів та високотехнологічних напрямків бізнесу. Доцільним є також створення позабюджетної підтримки інновацій та розробка дієвих норм для реалізації спільних інвестицій, зокрема щодо інвестиційних фондів, які наці-

\section{ДЕЦЕНТРАЛІЗАЦІЯ ТА ЗАПРОВАДЖЕННЯ ШИРОКОЇ} РІЗНОМАНІТНОСТІ У ТЕХНОЛОГІЯХ ВИРОБНИЦТВА

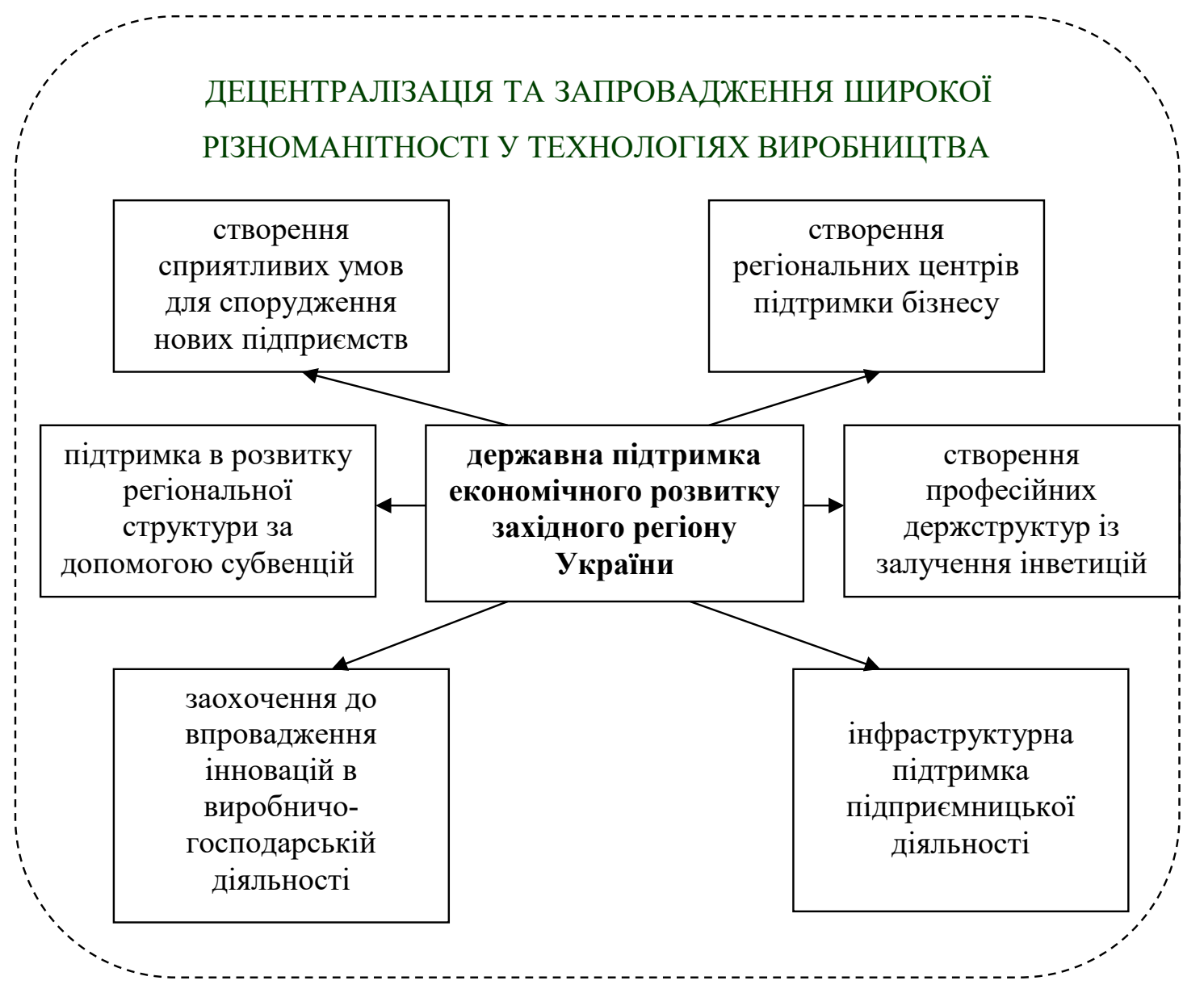

Рис. 2. Шляхи державної підтримки економічного розвитку західного регіону України Джерело: [11] 
лені на фрінансування росту молодих компаній 3 інноваційних розробок. Не менш важливим $€$ державна підтримка компаній у напрямку підвищення екологізації спираючись на національні та міжнародні екологічні норми.

Можна запропонувати такі шляхи державної підтримки інноваційного розвитку та здійснення наукових досліджень для практичного впровадження наукових розробок: виявлення найперспективніших інноваційних проектів для їх впровадження в виробничо-господарську діяльність за допомогою різноманітних конкурсів та ярмарків; зростання кількості державного замовлення з підготовки спеціалістів інноваційного підприємництва, так званих менеджерів з інновацій та спеціалістів у венчурному інвестуванні; особливу увагу слід приділити удосконаленню рекреаційного та туристичного напрямів бізнесу. Саме туристичний бізнес через різноманітність форм відпочинку сприяє збільшенню діапазону видів та проникнення в нові сорери виробничо-господарської діяльності.

Сорера послуг стрімкіше розвиватиметься при рості економіки, змінах в структурі економіки та збільшенню міжнародних зв'язків, а цьому в свою чергу сприяє культурна та природна особливість регіону. Так, сільський туризм $€$ ключовим фрактором в культурному збагаченні периферії та можливості зменшення безробіття в сільських регіонах.

Актуальним для західного регіону України $€$ розвиток туристичного виду бізнесу, що в свою чергу веде до розширення рекреаційного напряму. Стимулювання розвитку туристичного бізнесу $є$ запорукою росту його конкурентоспроможності та закріплення стійкої позиції на світовому ринку туристичних послуг.

Розвиток готельно-відпочинкових послуг потребує реструктуризації. Для виходу на конкурентні міжнародні позиції слід запровадити нові технології, ґрунтовно оновити готельну базу, залучити значні капіталовкладення.

Великі інвестиції в курортно-рекреаційний напрям туристичного бізнесу можна залучити через організування тендерів щодо придбання і спільного володіння землею, як державою так і приватними структурами в рекреаційних зонах для створення там відпочинкових комплексів. Сприяння з боку держави та міжнародні інвестиційні можливості дозволять значно розширити санаторно-курортний відпочинок та при умові значного збільшення кількості послуг в санаторному оздоровленні. Таким чином, збільшивши кількість сана- торно-курортних відпочинкових комплексів стане можливим запровадження широкого спектру платних послуг в їх структурі, а також збільшення кількості підприємств 3 надання побутових і інших послуг при цих санаторнокурортних комплексах.

Збільшення інвестиційного потенціалу регіону можливе через реструктуризацію інсрраструктури, що в свою чергу є розвитком нових шляхів регіонального розвитку [12].

Вповільнення економічного розвитку регіонів й держави вцілому зумовлене слабким рівнем розвитку як виробничої так і не виробничої господарки. Сьогодні $є$ потреба в ґрунтовній модернізації енергетики, ЖКГ, транспортних мереж, інше. Тому, в першу чергу слід зосередитися на реструктуризації існуючої глобальної інфрраструктури з виходом на їі відповідний світовий рівень. Наступним кроком це ж саме тільки на регіональному рівні, рівні мегаполісів і т.д. Такий напрям реструктуризації призведе до більш тісної взаємодії між регіонами, збільшенню можливості просторової мобільності жителів, зменшенню безробіття, збільшенню інвестиційної привабливості регіонів.

Участь держави в спільному з місцевими органами управління і місцевими органами самоврядування, фрінансуванні інвестиційних проектів повинна бути націлена на розвиток соціальної та виробничо-господарської інорраструктури [13].

Зміцнення конкурентних позицій регіон може досягти через поглиблення соціальної та виробничо-господарської інсрраструктури з подальшим виведенням її на міжнародний рівень.

Підтримка з боку держави, щодо реструктуризації соціальної та виробничо-господарської інфрраструктури в умовах проведення політики регіонального розвитку мусить бути націлена на: удосконалення транспортної інфрраструктури в довготерміновому аспекті вирішення питань збалансованого розвитку всіх видів транспорту і дорожнього господарства, а також місцевих транспортних мереж та повномасштабного використання різного виду транспорту для перевезення конкретно визначеного вантажу, що дозволить піднести внутрішні можливості як регіону так і держави в цілому. Також в умовах здійснення політики регіонального розвитку державна підтримка має бути націлена на: удосконалення інораструктури транспорту і реалізовуватися за допомогою впровадження програм 3 удосконалення державної транспортної системи 
та впровадження проектів щодо збільшення кількості міжнародних транспортних шляхів; реструктуризацію житлово-комунального господарства через виведення його на конкурентні позиції, його демонополізацію 3 подальшим переходом в приватну власність, що призведе до вкладення в ЖКГ приватних інвестицій.

Важливим $є$ державна підтримка 3 фрінансування проектів для органів місцевого самоврядування. Серед таких проектів відзначимо: недопущення техногенних катастрофр та аварій техногенного характеру; утворення соціального житлового фонду; глобальної перебудови тепломереж, водопостачання та водовідведення з встановленням засобів їх обліку; удосконалення як мереж так і самого електротранспорту у всіх містах України; запровадження діючих організацій з охорони навколишнього природного середовища; підвищення екологічного стану регіонів, при цьому роблячи наголос на покращення умов для господарств 3 забезпечення водних ресурсів.

Формування конкурентоспроможної економіки реґіону можливе на основі розвитку інноваційних видів економічної діяльності 3 високою доданою вартістю, зокрема галузей біоекономіки, які використовують біоресурси (в тому числі й біовідходи), як сировину для виготовлення продукції.

Серед основних галузей біоекономіки Західного регіону які відіграють вагому роль в структурі економіки регіону можна виокремити:

- лісовиробничий комплекси (лісогосподарство та лісозаготівля; деревообробка; виробництво столярних виробів; виробництво меблів; покриття для підлоги та облицювання стін; покрівельні роботи; целюлозно-паперова виробництво);

- сільськогосподарський комплекс (рослинництво; тваринництво; рибне господарство);

- харчову промисловість (виробництво продуктів харчування; виробництво напоїв; виробництво тютюнових виробів);

- біоенергетика;

- біотехнології.

Важливим аспектом у сприянні подальшого розвитку біоекономіки може стати фрормування системи ресурсо-ефрективності для підприємств, що працюють із біоресурсами, яка буде ґрунтуватись на принципах «каскадної економіки» (відходи одного виробництва $\epsilon$ сировиною для іншого).

Значну увагу в реструктуризації регіональної економіки слід приділяти модернізації очисних споруд, розширенню каналізаційних мереж, збільшенню використання технологій, які продукують енергію з відновних джерел; обліку теплової енергії та води на всіх етапах - від виробництва до споживання; зменшенню рівня антропогенного забруднення довкілля та підвищення раціональності у природо-ресурсному користуванні; збільшення лісових насаджень відповідно до науково обґрунтованого рівня; забезпечення недопущення паводків шляхом спорудження відповідних захисних конструкцій; ґрунтовний розвиток інфрраструктури освіти і науки всіх рівнів; всебічне сприяння розвитку науки і техніки, IT-бізнесу.

Запровадження в практику цих пріоритетних шляхів розвитку повинно здійснюватися завдяки реструктуризації всіх можливих інорраструктурних елементів в першу чергу мегаполісів та міст разом з їх перифрерією, що дозволить збільшити їх населення і як наслідок збільшення споживання, капіталу і т.д.

Розвиток науково-культурної, екологічної, суспільної, економічної сорер обумовлений посиленням стимулюючої ролі створених умов в розвитку мегаполісів та міст з їх перифрерією. Тут в першу чергу наголос повинен робитися на реструктуризацію телекомунікаційних мереж, розвиток науки, а також всіх рівнів освіти, розвиток мистецтва і культури, тощо.

Підтримка з боку держави в цьому напрямку буде доцільною у випадках реструктуризації соціальної та виробничо-господарської інфрраструктур регіонів, що матиме на меті збільшення інвестицій; розширення ринків збуту товарів; реструктуризацію освітніх програм під потреби регіону в першу чергу простех освіти, а також інших вищеописаних суміжних шляхів державної підтримки притаманних загально-регіональному рівню.

Швидкі темпи розвитку телекомунікаційних мереж та IT-індустрії призводять до інорормаційної модернізації в суспільному розвитку населення. Зміцнення конкурентних позицій України на світовому ринку сприятиме широкому впровадженню інтернету у всіх куточках нашої держави. Це дозволить в повній мірі використовувати глобальну мережу для торгівлі, поширення інформації про підприємства, реклами, тощо, а також підвищить комп'ютерну грамотність населення.

Сьогодні ні регіональний, ні місцевий розвиток не можливий без використання інформаційних технологій. 3 ними також тісно пов'язані поняття збереження культурних цінностей, охорона навколишнього природного середовища, інше. Інорормаційні технології сього- 
дення $є$ основою з забезпечення інсрормацією суб'єктів господарської діяльності щодо регулюючих норм і актів введених регіональною владою і органами місцевого самоврядування.

Стрімкий розвиток інформаційних технологій продукує динамічний розвиток економіки в цілому, зменшення безробіття та ріст конкурентоздатності регіонів.

Висновки. Можемо обґрунтовано стверджувати, що реструктуризацію економічного потенціалу західного регіону України слід проводити у таких напрямках: посилення збалансованості соціально-економічного і екологічного розвитку; розвиток біоекономіки; впровадження інновацій в усіх галузях господарства західного регіону України, особливо інноваційний розвиток виробничої, комунікаційно-інфрормаційної, соціальної інфрраструктури; інтенсивний розвиток рекреаційного комплексу.

\section{СПИСОК ВИКОРИСТАНИХ ДЖЕРЕЛ:}

1. Черевко О.В. Стратегія соціально-економічного розвитку регіонів України : [монограсрія]. Черкаси : Брама-Україна, 2006. 424 с.

2. Адамов Б.І. Організаційно-економічні основи управління розвитком міст. Київ : Грот, 1998. 215 с.

3. Алексеев О.Б. Стратегическое управление в государственном и муниципальном секторах / Сост. и ред. А.Е. Балобанов, О.И. Генисаретский. Москва : Экономика, 2000. 259 с.

4. Алексеева М.М. Планирование деятельности фрирмы. Москва : Финансы и статистика, 1997. 248 с.

5. Анисимов О.С. Стратегическое мышление и развитие профессионализма управленческой деятельности // Стратегическое планирование в муниципальном управлении: Введение в предмет / сост. и ред. А.Е. Балобанов, О.И. Генисаретский. Москва : Московский общественный научный фонд, 2000. 273 с.

6. Без'язичний В., Мамонова В. Формування стратегії соціально-економічного розвитку регіону. Актуальні проблеми державного управління. 2000. № 1. С. 108-117.

7. Бланк И.А. Стратегия и тактика управления финансами. Киев : МП «ИТЕМ Лтд»: СП «АДЕФ-Украина», 1996. $534 \mathrm{c}$.

8. Бойко 3.М. Проблеми оптимальної стратегії розвитку України в умовах глобалізації. Економічні проблеми ринкової трансформації України: Тези доповідей Всеукраїнської наукової конфреренції 3-4 грудня 2002 р. Львів, 2002. С. 31-32.

9. Мошенець О.С. Актуальність дослідження механізму регіонального розвитку. Соціально-економічні дослідження в перехідний період. Інвестиції і реструктуризація економіки регіону (Щорічник наукових праць) Випуск XI / НАН України. Інститут регіональних досліджень. Львів, 2000. С. 328-334.

10.Балян А.В. Міжрегіональне та транскордонне співробітництво України за умов розширення Європейського Союзу. Ужгород : Ліра, 2005. 325с.

11. Софріщенко І. Співробітництво Україна - ЄС: особливості сучасного етапу та можливості для територіальних адміністративних одиниць. Економічний часопис-XXI. 2009. № 1/2. С. 32-37.

12. Стадницький Ю.І., Загородній А.Г. Розміщення продуктивних сил (теоретичні основи) : навч. посіб. Київ : Знання, 2008. 351 c.

13.Закон України «Про транскордонне співробітництво» від 24.06.2004 p. № 1861-IV. URL: https://zakon.rada.gov.ua/laws/show/1861-15\#Text (дата звернення: 14.06.2021).

\section{REFERENCES:}

1. Cherevko O.V. (2006) Stratehiya sotsial'no-ekonomichnoho rozvytku rehioniv Ukrayiny [monohrafiya] [Strategy of socio-economic development of the regions of Ukraine: [monograph]]. Cherkasy: Brama-Ukrayina, $424 \mathrm{p}$.

2. Adamov B.I. (1998) Orhanizatsiyno-ekonomichni osnovy upravlinnya rozvytkom mist. [Organizational and economic bases of urban development management]. Kyiv: Hrot, $215 \mathrm{p}$.

3. Alekseev O.B. (2000) Stratehycheskoe upravlenye $v$ hosudarstvennom y munytsypalnom sektorakh [Strategic management in the state and municipal sectors] / sost. y red. A.E. Balobanov, O.Y. Henysaretskyy. Moscow: Ekonomyka, $259 \mathrm{p}$.

4. Alekseeva M.M. (1997) Planyrovanye deyatel'nosty fyrmy. [Planning the company's activities.]. Moscow: Fynansy i statystyka, $248 \mathrm{p}$.

5. Anysymov O.S. (2000) Stratehycheskoe myshlenye y razvytye professyonalyzma upravlencheskoy deyatelnosty [Strategic thinking and development of professionalism of administrative activity]. Stratehycheskoe planyrovanye $\vee$ munytsypal'nom upravlenyy: Vvedenye $v$ predmet. sost. y red. A.E. Balobanov, O.Y. Henysaret-skyy. Moscow: Moskovskyy obshchestvennyy nauchnyy fond, $273 \mathrm{p}$. 
6. Bezyazychnyy V. (2000) Formuvannya stratehiyi sotsialno-ekonomichnoho rozvytku rehionu [Formation of the strategy of socio-economic development of the region]. Aktualni problemy derzhavnoho upravlinnya, no. 1, pp. 108-117.

7. Blank Y.A. (1996) Stratehyya y taktyka upravlenyya fynansamy. [Financial management strategy and tactics]. Kyiv: MP «YTEM Ltd»: SP «ADEF-Ukrayna», 534 p.

8. Boyko Z.M. (2002) Problemy optymal'noyi stratehiyi rozvytku Ukrayiny v umovakh hlobalizatsiyi [Problems of optimal strategy of development of Ukraine in the conditions of globalization]. Ekonomichni problemy rynkovoyi transformatsiyi Ukrayiny: Tezy dopovidey Vseukrayins'koyi naukovoyi konferentsiyi 3-4 hrudnya 2002 r. Lviv, pp. 31-32.

9. Moshenets O.S. (2000) Aktualnist doslidzhennya mekhanizmu rehional'noho rozvytku [The relevance of the study of the mechanism of regional development]. Sotsialno-ekonomichni doslidzhennya $v$ perekhidnyy period. Investytsiyi i restrukturyzatsiya ekonomiky rehionu (Shchorichnyk naukovykh prats'), vol. XI / NAN Ukrayiny. Instytut rehional'nykh doslidzhen. Lviv, pp. 328-334.

10. Balyan A.V. (2005) Mizhrehionalne ta transkordonne spivrobitnytstvo Ukrayiny za umov rozshyrennya Yevropeyskoho Soyuzu [Interregional and cross-border cooperation of Ukraine in terms of enlargement of the European Union]. Uzhhorod: Lira, 325 p.

11. Sofishchenko I. (2009) Spivrobitnytstvo Ukrayina - YES: osoblyvosti suchasnoho etapu ta mozhlyvosti dlya terytorialnykh administratyvnykh odynyts [Cooperation Ukraine - EU: features of the current stage and opportunities for territorial administrative units]. Ekonomichnyy chasopys-XXI, no. 1/2, pp. 32-37.

12. Stadnytskyy YU.I., Zahorodniy A.H. (2008) Rozmishchennya produktyvnykh syl (teoretychni osnovy): navch. posib. [Placement of productive forces (theoretical foundations): textbook. way]. Kyiv: Znannya, $351 \mathrm{p}$.

13. Zakon Ukrayiny «Pro transkordonne spivrobitnytstvo» [Law of Ukraine "On Cross-Border Cooperation"] vid 24.06.2004 r. № 1861-IV. URL: https://zakon.rada.gov.ua/laws/show/1861-15\#Text (accessed June 14, 2021). 